\title{
The Teacher Efficacy in Developing Character Education of Integrated Islamic Schools Students in Indonesia
}

\author{
Salamiah Sari Dewi , Universitas Muhammadiyah Yogyakarta \\ Sutrisno Sutrisno, Universitas Islam Negeri Sunan Kalijaga \\ Abd. Madjid , Universitas Muhammadiyah Yogyakarta \\ *Fitriah M. Suud, Universitas Muhammadiyah Yogyakarta, fitriahmsuud@gmail.com \\ *Corresponding Author
}

\begin{abstract}
The teacher is a professional educator who plays an important role in developing students' self potentials, character building and creating a positive nation civilization in order to educate the nation's life. The character of the Indonesian nation which still tends to be negative nowadays causes moral bankruptcy, acts of violence, high personal egoism, the extent of various conflicts and social pleasures in society. Thus, teachers really need to have the self efficacy that they are able to educate and develop the character education of their students in order to create a dignified generation of the nation. Teacher's efficacy affects academic achievement, and student learning motivation, teacher teaching quality, teacher psychological well-being, teacher achievement, job satisfaction, and teacher work commitment. This study aims to answer the question of how the influence of age, experience and religiosity on the teaching efficacy of teachers in developing students' SAFT character education. This study uses descroptive quantitative method. Respondents involved 739 teachers of SDIT in North Sumatra Province. They were asked to fill in questionnaires about age range and experience, religiosity scale and teacher efficacy scale in developing student character education via online. This study found that age and teaching experience did not significantly influence teacher efficacy. However, religiosity have shown to significantly influence teacher efficacy. Implications in this study will be discussed further
\end{abstract}

keywords character education, experience, religiosity, teacher's efficacy, elementary school Received: 22.11.2020 Accepted: 15.12.2020 $\quad$ Published: 12.01.2021

\section{INTRODUCTION}

Teachers are the main axis of education that determines the progress of a country in the future (Heri, 2019). Teachers play a very important role in student learning in schools (Gentrup, Lorenz, Kristen \& Kogan, 2020, Dietrich, Dicke, Kracke \& Noack, 2015). Teachers are the most influential component in creating quality educational processes and outcomes (Mulyasa, 2005). Therefore, teachers are considered to have a very important role in creating quality education in order to achieve the progress of a country in the future. Since 2010, the world of education in Indonesia can be regarded as the world of character education. The reason is, since the beginning of 2010 or precisely on January 14, 2010, the government through the Ministry of National Education launched the program "Cultural Education and Nation Character" as a national movement. After this program was launched, several Directorates General with the existing directorates immediately followed up by compiling the guidelines for the implementation of Cultural and National Character Education. In fact, other ministries are not left behind also given the task to develop and implement character education in their environment. In the Ministry of Education and Culture, a "Character Education Master Design" was developed. Then at the Directorate of Primary and Secondary Education has also made an implementation plan by developing a syllabus that is associated with the values of the nation's character.

The government's serious efforts in realizing the ideals of good education through the Strengthening Character Education (SCE) movement are caused by the condition of the Indonesian nation that is being hit by character degradation that results in moral bankruptcy, such as rampant acts of violence, strengthening personal and collective egoism, rampant and the extent of various conflicts, as well as the widening of various gaps that fill public coverage. Suyata (2011) states that the grim conditions can be caused by the neglect or even the absence of conceptualization of Indonesian character and its application in character development and education which is placed on the concept of human development as a person or community.

The Ministry of Women's Empowerment and Child Protection (KPPPA) in the Indonesian Child Profile (Ministry of Women's Empowerment and Child Protection, 2019) states that juvenile delinquency 
behavior or adolescent behavior with negative characters is very alarming. In fact, for the negative character of the weight level of adolescents who are in conflict with the law reaches more than $40 \%$ and $30 \%$ get imprisonment with a total of 3,469 children. Whereas for children and adolescents (7-17 years) with active smoking habits reach 1.33\%. In Nurjannah's research (2014), the behavior of adolescents with negative characters in Panca Budi Medan High School with low levels such as being late to school, littering, making noise during learning reached $98.3 \%$, whereas with moderate levels such as fighting and disrespect for teachers reached $1.7 \%$.

Cases of delinquency of children and adolescents with negative characters in North Sumatra of concern are abuse and truancy during study hours. Cases of harassment were recorded among elementary school students, especially in Labuhanbatu Utara North Sumatra sub-district in 2019 (new.detik.com). While cases of truancy of students during study hours were found in Medan Belawan sub-district namely 12 elementary and junior high school students netted by a love raid at an internet shop during lesson hours (kitakini.news).

Then in the research of Sirait, Siddik and Zubaidah (2017) conducted at Madrasah Aliyah Negeri 1 Medan, it was found that the character of students who tended to be negative still had to be improved. Behavior of students with negative characters includes lack of religious values, dishonesty (Suud, et al., 2020), lack of tolerance, lack of discipline, lack of national spirit or love for the motherland, lack of interest in reading and social care. Therefore, it is necessary to implement moral education which is not only in the field of moral education studies, but all teachers in the field of study.

Coupled with research conducted by Asmara \& Ridho (2016) concerning behavior with negative characters in the form of associations with motorcycle gangs whose majority of the actors are teenagers in the city of Medan. This is certainly very disturbing for the residents, because not only robbing, but the actions of the motorcycle gang can also hurt or even eliminate the lives of its victims. Finally, research on the phenomenon of adolescent behavior with negative characters in the use of narcotics, illegal drugs and premarital sexual behavior in Tanjung Morawa District, Deli Serdang Regency, North Sumatra Province, was conducted by Perdana (2016). In this study, of a total of 9,219 HIV / AIDS cases in North Sumatra province, Tanjung Morawa district was the district with the largest case of premarital sexual behavior in North Sumatra.

In connection with the problem above, the Coordinating Ministry for People's Welfare (Kemenko Kesra) in 2010 actually issued a national policy on Nation Character Development, which is expected to be responded to by the Ministry of National Education. It is hoped that the policy is not just a discourse but an action plan in education programs throughout education units. However, unfortunately, the current learning model tends to emphasize theoretical by only focusing on the cognitive aspects so that the educational outcomes up to now have still drawn a lot of criticism because the ability to respond, tolerance, empathy, and self-control as one of the characters to be developed is still weak (Zamakhsari, et al., 2020). The curricular program has not yet specifically touched on the themes of national character development, which results in low personal skills.

One environment that contributes to developing character education is the school. In research conducted by Suud, Madjid and Sutrisno (2019), schools are places where character education is formed and developed. Schools are not only a place to gain knowledge but also a place to shape and develop positive characters (Muwaga, et al., 2020). This is where the role as a teacher is very important so that a teacher must have confidence in himself that he is able to carry out their duties properly.

With the increasing insistence on education reform in this country, quality teaching and teachers are a hot issue that must be addressed wisely. Teachers and schools are increasingly demanded to meet education standards. More specifically, in the context of education and schooling in Indonesia, the quality of teaching needs immediate attention. It has long been recognized that teaching efficacy is an important factor in the development of quality human resources and is even used as an indicator in determining the human development index (HDI) (Setiadi: 2007).

According to Bandura (1977), one's belief in succeeding in carrying out a task or goal is also called self-efficacy. Self-efficacy of each person depends on the context and specific tasks, so that someone can be sure to do a task, but not sure of the other tasks. The teacher's self-efficacy is the belief that the teacher has that he is able to get students involved in teaching and learning activities, even though the student has difficulty or is less motivated to learn (Guskey \& Passaro, 1984).

The teacher's self-efficacy influences academic achievement, and student learning motivation, teacher teaching quality, teacher psychological well-being, teacher achievement, job satisfaction, and teacher work commitment (Zee \& Koomen, 2016, Klassen \& Chiu, 2010). So it can be concluded that the teacher's self-efficacy is a belief owned by the teacher that he is able to organize teaching and learning activities well that can affect academic achievement, and student motivation, teacher teaching quality, 
teacher psychological well-being, teacher performance, job satisfaction, and teacher work commitments which is a predetermined educational goal.

Previous studies have found that teacher efficacy is related to several demographic variables, such as age (Houkarnau \& Sibley, 2010, Lee \& Tsai, 2010 and Milson \& Mehlig, 2002) and teaching experience (Lowe, 2013, Erawati, 2012, Lee \& Tsau, 2010, Huang \& Liu, 2007 and Campbell et al. 1996). Age, by definition, is the length of life that is from birth to the present. Determination of age is done by using a number of years. Meanwhile, teaching experience is anything that has been experienced in teaching with regard to a period of time.

Age is often used as a cause of decreased performance of a person, psychomotor, and one's ability to understand. Maharani (2011) research results show that teachers aged 46-50 years and over have high efficacy compared to younger teachers. Ghanizadeh and Moafian (2011) also found that the older the teachers, the greater their beliefs about self-efficacy in a study of pedagogical success. But on the contrary, in a study conducted by Issom \& Amelia (2015), the higher the age of a teacher, the lower the self-efficacy in teaching, especially learning using the 2013 curriculum.

Teaching experience is essentially a summary of one's understanding of the things they experience in teaching, so that the experienced things have been mastered, both knowledge, skills and values that are united in him (Widayoko, 2005). The teacher's teaching experience can be measured by the number of years he teaches. In a study conducted by Johari, et al. (2009) states that teachers who have more than seven years of teaching experience have high efficacy in teaching in the classroom. Also, research conducted by Issom and Amelia (2015) also found that experience was influential in improving teacher teaching efficacy.

In the context of the Islamic point of view, there needs to be an aspect of the teacher's religiosity, so that faith and devotion become the basis of self-confidence. One of them is religious character who believes in the example of the Prophet Muhammad's example of his attitude and behavior in daily life, such as honesty (Siddiq), trustworthy (amānah), communicating well (tablīg), and intelligent (fațānah) (Suud et al., 2019).

During the past three decades, the world of education in Indonesia has received new arrivals, the Integrated Islamic School (SIT). Integrated Islamic School (SIT) is one of the schools that is very focused on the formation and development of religious character. SIT is a school that combines general education and religious education into a curriculum in the organization of education. SIT applies the concept of Islamic education based on the Qur'an and Hadith . The emergence of SIT in the world of education in Indonesia seems to be welcomed positively by the people of Indonesia. This can be seen from the increasing number of SITs that have sprung up throughout Indonesia, especially in urban and sub-urban environments.

The research conducted by Barni, Danioni and Benevene (2019) found that teacher religiosity drives their goals and behavior in school. The religious character of the teacher can support the subjective well-being and efficacy of the teacher's teaching (Khaidir\&Suud, 2020). Teacher efficacy, namely teacher confidence in their ability to effectively handle assignments, obligations, and challenges related to their professional activities, plays a major role in influencing important academic outcomes (for example, student achievement and motivation) and student welfare in education.

Based on the whole description above, the researchers found that the role of teachers in SIT was different from teachers in public schools. In addition, the importance of the teacher's self-efficacy in teaching is influenced by age, teaching experience and teacher religiosity. Therefore, this study was conducted to empirically examine the efficacy of teaching teachers in developing student character education, specifically relating to aspects of the demographic psychology of age, demographic psychology aspects of teaching experience (Suud, F. M, et al., 2020) and religious character as aspects of religiosity in the perspective of Islamic psychology in Integrated Islamic Schools in the province of North Sumatra with the title of the research "Efficacy of Teachers in Developing Character Education of Integrated Islamic School Students in North Sumatra".

\section{METHODS}

\section{Research Design}

The research design carried out to determine the factors that influence the teaching efficacy of teachers in developing character education of Integrated Islamic Schools students in North Sumatra Province is a quantitative descriptive approach. Descriptive research is research that is intended to investigate situations, conditions, conditions or other things that have been mentioned, and the results will be presented in the form of research reports. In this descriptive study, the researcher did not add, manipulate or even change, the object or area of research, and the researcher only photographed the events that occurred in the object or region under study, then all events that have been photographed in the form of 
research reports are straightforward, straightforward, as is without any exaggeration (Arikunto, 2010). Quantitative descriptive research, in this study, is explanatory research, namely research conducted to explain the causal relationship between variables through testing hypotheses that are formulated (often called explanatory research) (Sugiono, 2008).

\section{Subjects of the Research}

According to Arikunto (2006), research subjects are subjects that are intended to be investigated by researchers. Research subjects or respondents are people who are asked to provide information about a fact or opinion. So, the research subject is a source of information dug out to uncover facts in the field. The technique in taking subjects in this study was purposive sampling. Purposive sampling according to Sugiyono (2011) is a sampling technique with certain considerations. There were 739 research subjects who have filled out questionnaires (questionnaires) from 66 Integrated Islamic Primary Schools both those who have joined the Integrated Islamic Schools Network and those who have not joined the Integrated Islamic Schools Network in Indonesia which are spread across North Sumatra Province.

\section{Data Analysis Technique}

The data analysis technique used to discuss each problem in this study, the researcher used the Structural Equation Model, which is operated through the Moment of Structure Analysis Program. Structural Equation Model is a data analysis technique (statistical technique), which allows researchers to test a series of complex relationships simultaneously. The complex relationship can be built between one or more dependent variables with one or more independent variables.

\section{Requirements Analysis}

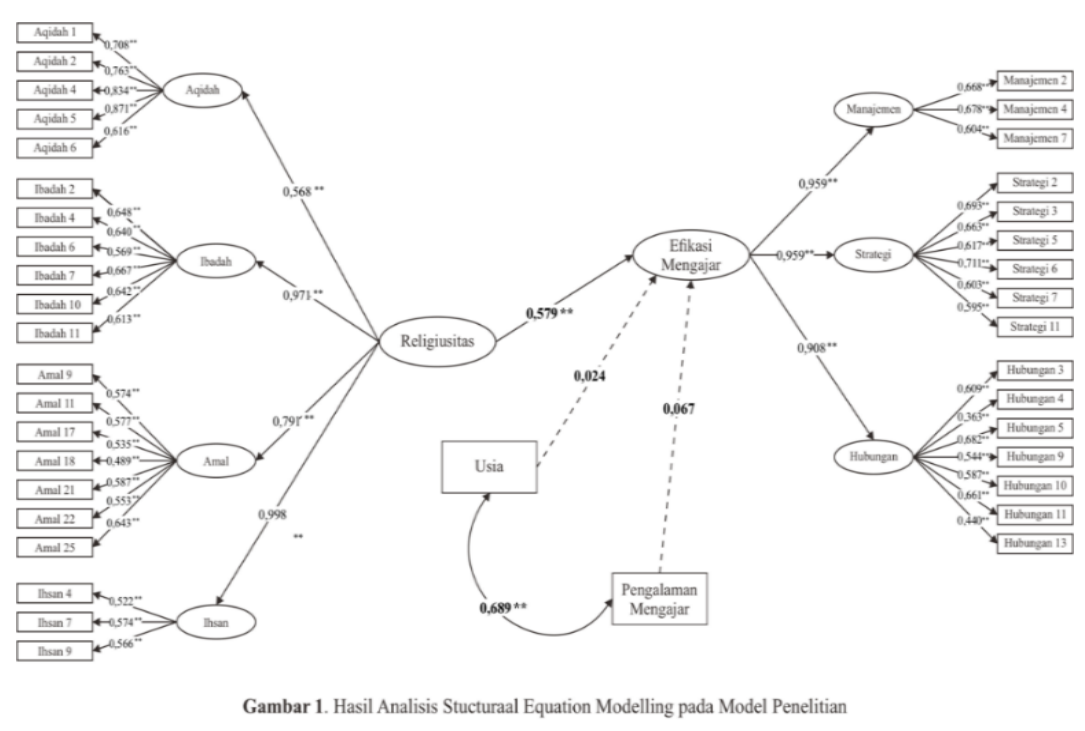

The articles need to be not published elsewhere previously. If the article has been presented at any seminar or conference, the name of the conference, the institution where it has been presented and the date of the presentation needs to be mentioned. The Journal is written in English. Thus, the articles need to be written in this language. The title of the article must be written in capital letters, using font size 11 and bold. One line space must be left after the title. The name and surname of the author(s), their title, and the institution they work for and its web site must be written.

\section{The Loading}

factor value of each indicator must have a value of $\geq 0.4$. While the reliability of the measurement model is seen from the value of Construct Reliability (CR) and variance extraced (VE). The level of reliability of CR $\geq$ 0.70 is acceptable for studies that are still exploratory. Another measure of reliability is variance extracted as a complement to variance extracted $\geq 0.5$.

\section{Hypothesis}

a) Ha1: $\beta 1 \neq 0$; There is a significant influence between age on the level of teaching efficacy of teachers in developing the character education of Integrated Islamic School students in North Sumatra Province. 
b) Ha2: $\beta 2 \neq 0$; There is a significant influence between experience on the level of teaching efficacy of teachers in developing the character education of students of Integrated Islamic Schools in North Sumatra Province.

c) Ha3: $\beta 3 \neq 0$; There is a significant influence between experience on the level of teaching efficacy of teachers in developing the character education of students of Integrated Islamic Schools in North Sumatra Province.

\section{Goodness of fit}

Goodness of fit index Criteria, Chi-square The smaller the better, Normed Chi-square $<2$. Probability $>0.05$, CFI $>0.95$ or $>0.90$, GFI $>0.95$ or $>0.90$, TLI $>0.95$ or $>0.90$ RMSEA $>0.05$ with a tolerance of up to 0.08 .

\section{RESULTS}

In the context of this study, the magnitude of the influence of the variables of age, length of teaching and religiosity. Meanwhile, the magnitude of the influence and research model that fits the data are shown in Figure 1.

Hypothesis 1: Age influences the efficacy of teaching

The analysis shows that age has an influence on the efficacy of teaching with beta $0.024(p>0.05)$. However, although increasing age can increase the efficacy of teaching teachers, the increase is not significant. In other words, age does not significantly influence the teaching efficacy of teachers. Thus, the first hypothesis in this study was rejected.

Hypothesis 2: Length of teaching has an effect on the efficacy of teaching

Based on Figure 1, the effect of teaching experience on teacher teaching efficacy is illustrated by the dotted arrow. This arrow indicates that the influence that exists or beta that is equal to 0.067 is not significant ( $p>0.05)$. That is, teaching experience has no significant effect on the teaching efficacy of teachers. Thus, the second hypothesis in this study was rejected.

Hypothesis 3: Religiosity influences the efficacy of teaching

Figure 1 shows that religiosity has an influence on the efficacy of teaching teachers with a beta of 0.597 and a significance below 0.01 . That is, an increase that occurs in teacher religiosity can improve their efficacy in teaching. In other words, religiosity has a significant positive effect on the teaching efficacy of teachers. Therefore, the third hypothesis in this study was accepted.

\section{DISCUSSION AND CONCLUSIONS}

In various literature studies, character education becomes an important part of developing the nation's character through education. The character of the nation will be formed in accordance with the uniqueness and identity of the nation when the involvement of government structures provides a policy of the importance of all elements of society being actively involved. Therefore character education is needed in an era of openness. This term was popularized by Lickona. Lickona (1991) is the main originator of character education that believes in the existence of absolute morals, so absolute morals need to be taught to young people so that they understand exactly what is good and right.

Character education has a higher meaning than moral education, because it is not just teaching what is right and what is wrong. More than that character education instills habits (habits) about good things so that students become understand (cognitive) about what is good and wrong, able to feel (affective) good values and want to do it (psychomotor). As Aristotle said, the character is closely related to "habit" or habits that are continually practiced and practiced.

In Islam, the noble character of a Muslim can be seen from the personality of the Prophet Muhammad who had 4 well-known characters namely: Siddiq, Amanah, Fathonah and Tabligh. 1) Siddiq (honest) says true, one word, one deed, obey the principle, keep the promise, be independent, thankful, worship. 2) Trust (trustable, trustworthy) (Suud, 2019), responsible, disciplined, humble, sincere, fair, generous, and compassion. 3). Fathonah (smart), courage, obey the rules, work hard, be creative, be innovative, reasoning, be wise (wise). 4) Tabligh (reliable-communicative), self-confidence, respect for time, respect for the opinions of others and grace, caring, cooperation, mutual respect, tolerance, dare to take risks, happy (Bahiroh et al., 2019) to friendship Character education is a learning process that involves many components ( Masyhuri et al., 2020), one component in character education is the teacher.

In public schools or Islamic school, teachers are very important factors in developing the character of the younger generation. The ability of teachers to develop character education is closely related to the construct of teacher efficacy. Teacher efficacy is now a very important construct for understanding work 
behavior (Bandura, 1997). Efficacy is a belief in a person for his ability to mobilize 'motivation, cognitive resources, actions needed to achieve the expected goals.

From the results of this survey generally shows that Integrated Islamic School teachers in North Sumatra Province have teaching efficacy that is influenced by aspects of age, teaching experience and religiosity that can ultimately develop character education in students. This is indicated by the influence of each aspect on the level of teacher efficacy. The first aspect is that age influences but does not significantly influence the teaching efficacy of teachers in developing student character education. This is consistent with Bandura's (1994) findings that age does not correlate significantly with a person's efficacy because everyone varies greatly in how they live their lives effectively. Hoy and Tschannen-Moran (2007) in their research concluded that there was no significant difference between the efficacy of teaching and age in potential sources.

Furthermore, Voris (2011) analyzes the role of teacher efficacy on job satisfaction, age, and other demographic variables in education teachers, especially at the beginning of their careers. His findings showed no significant difference in the level of special efficacy of education teachers when analyzed by age. Bandura (1994) recognizes that age does not play a role in efficacy, but his research shows that there are significant changes in self-efficacy in people according to their age stages with the phases of their lives and how they handle situations that arise during these phases. For example when a new child is born, then there is no efficacy in him, until he grows even greater along with the increasing efficacy according to age and intellectual. When someone enters old age, their efficacy may decrease due to decreased ability in themselves such as memory performance. Long life periods bring big changes to life such as retirement, relocation, and even the loss of a friend or spouse. Every life period produces a new set of challenges. Successes and failures during these periods shape a person's self-efficacy and cause him to increase or decrease simultaneously.

In the second aspect, namely teaching experience, there is also no significant effect on the teaching efficacy of teachers. This is consistent with the findings of Mahfooz ul Haq and Mumtaz Akhtar (2013) and Maolosi (2013) in a separate study they found teaching experience could influence teacher efficacy in engaging students and teaching strategies because they became less motivated because of teaching time and fatigue. Research conducted by Knobloch (2006) shows that although being a beginner teacher has lower teaching efficacy in general, student teachers actually enter the teaching profession phase with an increasing level of efficacy due to the teaching experience gained during learning in higher education. Blackburn \& Robinson (2008) state that a large amount of research shows that novice teachers actually show a high level of self-efficacy in teaching the first few years of teaching.

The research conducted by Klassen and Chiu (2010) shows that teachers increase the efficacy of teaching through the early years and into the middle years of their teaching career but have decreased the efficacy of teaching due to entering the last stage of their teaching career. Gu \& Day (2007) produced findings similar to those found. That the majority of teachers in mid-career experience increases in motivation and commitment, whereas teachers who later in their careers experience a decrease in motivation and commitment in the later stages of a career, thereby reducing self-efficacy.

There are various difficulties and doubts arising when trying to understand conflicting research regarding self-efficacy in teaching and the effects experienced as experience in the teacher's role for teaching. Bandura believes that the efficacy of teaching a teacher may not be uniform from the beginning to the end of his career (Bandura, 1997). Therefore, according to Klassen \& Chiu (2010), the efficacy of teaching may change during a career caused by life events and career challenges. Self-efficacy is not static and does not reflect a lifelong process of development that changes according to circumstances (Gu, Q \& Day, 2007).

Then in the third aspect, religiosity. In contrast to the demographic aspects of age and experience, the aspect of religiosity shows a significant influence on the teaching efficacy of teachers in developing the character education of SDIT students in North Sumatra Province. Basically religiosity (religious character) is believed to be a model that is able to contribute in improving the self-efficacy of teachers in developing student character education. If the religiosity is high, it will affect the efficacy in teaching so that positive attitudes and strong influences are formed in shaping the character of students. Vice versa, low religiosity affects the teaching efficacy of teachers too low so that attitudes formed in themselves cannot be a good example for students in developing their positive character (Khan, 2010).

Based on the explanation above, religiosity is a determinant factor to be used as a model. In view of Social Learning Theory, a psychologist in the United States of America (Stanford University) Albert Bandura (1977), examines carefully the imitation events carried out by humans. Bandura through his research conducted a very famous experiment is the Bobo Doll experiment that shows children imitate such negative (aggressive) and positive (affectionate) behavior from the adults around them. This modeling can be a very important and powerful part of the process of character education and learning. 
Nevertheless, Bandura's theory has limitations in choosing or determining the ideal figure model. In the view of Islamic education learning through modeling is not something new more than 14 centuries ago, Islam has the power of a model figure that is the Prophet Muhammad who is the best example (uswah hasanah) to serve as an example of behavior in all his circumstances, except in the laws that are specific to him alone

\section{CONCLUSION}

Based on research that has been done, there is no significant influence of age and experience on the teaching efficacy of teachers in developing character education for students of Integrated Islamic Elementary Schools in North Sumatra Province. This proves that the higher age of the teacher does not significantly influence the higher efficacy of their teaching. The findings of this study contradict the hypothesis set by researchers. It also shows that the higher teacher experience does not significantly influence their teaching efficacy. The findings of this study also contradict the hypothesis that researchers set. However, in the aspect of religiosity, there is a significant influence of religiosity on the efficacy of teaching teachers in developing the character education of Integrated Islamic Elementary School students in North Sumatra. Statistically, religiosity shows a significant influence on the efficacy of teaching. This shows that the higher the level of teacher religiosity, the higher the teaching efficacy in developing the character education of Integrated Islamic School students in North Sumatra Province. The findings of this study are in accordance with the hypothesis that researchers set.

\section{REFERENCES}

Asmara, S., \& Ridho, H. 2016. Fenomena Geng Motor di Kota Medan. Medan: Universitas Sumatera Utara Bahiroh, S., Pratiwi, S. A., \& Fitriah, M. S. (2019). Improving Student Happiness Through The Snowball Throwing Method In The Implementation of Student Conceling Groups of State Vocational Schools 2 Depok Yogyakarta. Journal of Critical Reviews, 7(5), 2020.

Bandura, A. 1977. Social learning theory. New Jersy: Prentice-Hall, inc.

Bandura, A. 1994. Self-efficacy. In V.S. Ramachaudran (ed.), Encyclopedia of human behavior (Vol. 4, pp. 7181). New York: Academic Press.

Bandura, A. 1997. Self-efficacy: The exercise of control. New York: Freeman and Company.

Barni, D., Danioni, F. \& Denevene, P. 2019. Teachers' Self Efficacy: The Role of Personal Values and Moivations for Teaching. Italy: Catholic Universiy of Milan

Blackburn, J., \& Robinson, J. 2008. Assessing teacher self-efficacy and job satisfaction of early career agriculture teachers in Kentucky. Journal of Agricultural Education, 49(3), 1-11.

Campbell, J. 1996. A Comparison of Teacher Efficacy for Pre and in-Service Teacher in Scotland and America. Education, 117, 2-11.

Dietrich, J., Dicke, A.-L., Kracke, B., \& Noack, P. 2015. Teacher support and its influence on students' intrinsic value and effort: Dimensional comparison effects across subjects. Learning and Instruction, 39, 4554. https://doi.org/10.1016/j.learninstruc. 2015.05.007.

Erawati, M. 2012. Profil dan Faktor-Faktor yang Mempengaruhi Efikasi Guru Madrasah Ibtidaiyah Peserta Dual Mode System. Jurnal Psikologi 6(2), 417 - 440.

Gentrup, S., Lorenz, G.,Kristen, C., Kogan, I. 2020. Self-fulfilling prophecies in the classroom: Teacher expectations, teacher feedback and student achievement. Berlin: Humboldt Universitat zu Berlin. Learning and Instruction Volume 66, April 2020, 101296

Ghanizadeh, A \& Moafian, F. 2011. The Relationship between Iranian EFL Teachers' Sense of Self-Efficacy and their Pedagogical Success in Language Institutes. Iran: Islamic Azad University, Mashhad Branch

Gu, Q., \& Day, C. 2007. Teacher resilience: A necessary condition for effectiveness. Teaching and Teacher Education, 23, 1302-1316

Guskey, T. R., \& Passaro, P. D. 1994. Teacher efficacy: A study of construct dimensions. American Educational Research Journal, 31(3), 627-643.

Heri. 2019. Pengertian Guru: Definisi, Tugas dan Peran Guru Dalam Pendidikan. https://salamadian.com/pengertian-guru/

Houkamau, C.A., \& Sibley, C.G. 2010. Maori Cultural Efficacy and Subjective Wellbeing: A Psychological Model and Research Agenda. Soc Indic Res, DOI 10. 1007/s11205-010-9705-5, 121.

Hoy, A., \& Tschannen-Moran, M. 2007. The differential antecedents of self-efficacy beliefs of novice and experienced teachers. Teacher and Teacher Education, 23, 944-956

Huang, X., \& Liu, M. 2007. An Analysis of the Relationships between Teacher Efficacy, Teacher Self-Esteem, and Orientations to Seeking Help. Social Behavior and Personality, 35, 707-716. 
https://kitakini.news/31212/asyik-bermain-warnet-belasan-pelajar-sd-dan-smp-di-belawandiamankan-polisi/

https://news.detik.com/berita/d-4684544/viral-siswa-sd-di-sumut-dikeroyok-teman

Issom, F \& Amelia, D. 2015. Usia dan Pengalaman Mengajar terhadap Teacher Efficacy di Sekolah Dasar dengan Menggunakan Kurikulum 2013 Jurnal Penelitian dan Pengukuran Psikologi, Vol. 4, No. 1,

Johari, K., Islamail, Zurida., Osman, Shuki., \& Othman, Ahmad Tajudin. 2009. Pengaruh Jenis Latihan Guru dan Pengalaman Mengajar Terhadap Efikasi Guru Sekolah Menengah. Jurnal Pendidikan Malaysia 34(2): 3- 14.

Khan, Y. 2010. Pendidikan Karakter Berbasis Potensi Diri Mendongkrak Kualitas Pendidikan. Yogjakarta: Pelangi Publishing

Khaidir, Eniwati, and Fitriah M. Suud. "ISLAMIC EDUCATION IN FORMING STUDENTS'CHARACTERS AT ASSHOFA ISLAMIC HIGH SCHOOL, PEKANBARU RIAU." International Journal of Islamic Educational Psychology 1, no. 1 (2020): 50-63.

Klassen, R. M., \& Chiu, M. M. 2010. Effects on teachers' self-efficacy and job satisfaction: Teacher gender, years of experience, and job stress. Journal of Educational Psychology, 102(3), 741-756.

Knobloch, N. 2006. Exploring relationships of teachers' sense of efficacy in two student teaching programs. Journal of Agricultural Education, 47(2), 36-47

Kibtiyah, M., Suud, F. M., Masruri, S., \& Bashori, K. (2020). Self-Regulated Learnıng of Islam to Help Shape The Habit of Memorizing Al-Qur'an. PalArch's Journal of Archaeology of Egypt/Egyptology, 17(6), 9144-9143.

Lee, M-H., \& Tsai, C-C. 2010. Exploring Teacher's Perceived SelfEfficacy and technological Paedagogical Content knowledge with Respect to Educational Use of the World Wide Web. Instr Sci, 38, 1-21, DOI 10.1007/s11251-008-9075-4

Likhona, T. 1991. Educating for Characters. New York: The Ne York Times Company

Lowe, C. 2013. Practising and Preservice Teachers' Sense of Efficacy for Character Education. Spring: University of Connecticut

Maharani, D.R. 2011. Hubungan antara self Efficacy dengan Burnout pada Guru Sekolah Dasar Negeri X di Kota Bogor. Jurnal Psikologi

Mahfooz ul Haq \& Mumtaz Akhtar (2013). Middle-East Journal of Scientific Research, 18 (7), 950-957, DOI: 10.5829/idosi.mejsr.2013.18.7.11800

Masyhuri, S., Azhar, M., \& Suud, F. M. (2020). The Concept Of Happıness For Islamıc Community Of Melayu Kampar Riau Indonesı. Journal of Critical Reviews, 7(12), 833-838.

Moalosi, Waitshega Tefo Smitta. (2013). Teachers' Self Efficacy: Is reporting nonsignificant results essential? Journal of International Education Research - Fourth Quarter, 9 (4), 397-405.

Milson, A.J and Mehlig, L.M.(2002). Elementary School Teachers' Sense Of Efficacy For Character Education. The educational research, Vol. 96, No 1, pp 47-53 Pintrich, Paul R (2002) Motivation in Education Theory, Research and Aplication. 2nd Edition. New Jersey. Merill Prentice Hall.

Mulyasa. 2005. Menjadi Guru Profesional. Bandung: PT. Remaja Rosda Karya.

Muwaga, M., Nashori, F., \& Sholeh, A. (2020). The Impact of Social Environment on the Sexual SelfRegulation of University Students in Uganda. International Journal of Islamic Educational Psychology, 1(2), 75-88.

Nurjannah. 2014. Perilaku Kenakalan Remaja di SMA Panca Budi Medan. Medan: Universitas Sumatera Utara

Perdana. 2016. Perilaku Seksual Pranikah Remaja di Kecamatan Tanjung Morawa. Medan: Universitas Sumatera Utara

Profil Anak Indonesia. 2019. Kementerian Pemberdayaan Perempuan dan Perlindungan Anak (KPPPA) dan Badan Pusat Statistik

Setiadi, R. 2007. Efikasi Diri Dan Kinerja Guru Serta Hasil Belajar Literasi Siswa. Jakarta: Universitas Pendidikan Indonesia

Sirait, I., Siddik, D. \& Zubaidah, S. 2017. Implementasi Pendidikan Akhlak dalam Pengembangan Pendidikan Karakter di MAN 1 Medan. Pascasarjana Universitas Islam Negeri Sumatera Utara

Suud, F. M., Madjid, A., \& Sutrisno. 2019. The Study Of Educational Honesty Stages Implementation in An Indonesian School. Humanities \& Social Sciences $\quad$ Reviews, $\quad 7(4), \quad$ 502-510. https://doi.org/10.18510/hssr.2019.7467

Suud, F. M. (2018). Kepemimpinan Transformasional dan Implikasinya pada Pembentukan Budaya Jujur di Sekolah. Sukma: Jurnal Pendidikan, 2(2), 261-286.

Suud, F.M., Mudasirmudasir,, Azhar, M., Madjid, A. (2020) Student's academic cheating at Pondok Pesantren Teknologi Riau, Indonesia | Trampas académicas de los estudiantes en Pondok Pesantren Teknologi Riau, Indonesia, Utopia y Praxis Latinoamericana 25 (12), 72-80 
Suud, F. M., Sutrisno, S., \& Madjid, A. (2019). Educational Honesty: The Main Philosophical Value in School. TARBIYA: Journal of Education in Muslim Society, 6(2), 141-154.

Suud, F. M., Chaer, M. T., \& Setiawan, W. (2020). Implementation Educational Psychology Theories at Traditional Boarding School in Aceh. Journal of Critical Reviews, 7(9), 371-377.

Suyata .2011. Pendidikan Karakter: Dimensi Filosofis. Dalam Pendidikan Karakter dalam Perspektif Teori dan Praktik. Yoyakarta; UNY Perss.

Voris, B. 2011. Teacher efficacy, job satisfaction, and alternative certification in early career special education teachers. (Doctoral Dissertation). Retrieved April 2012 from the University of Kentucky Doctoral Dissertations at http://uknowledge.uky.edu/gradschool_diss/159

Widoyoko, E. P. S. 2005. Kompetensi Mengajar Guru IPS Kabupaten Purworejo. Dirjen Dikti.

Zamakhsari, Z., Masruri, S., \& Sutrisno, S. (2020). Self-Regulatory Learning Patterns of Disabled Students at UIN Sunan Kalijaga Yogyakarta. International Journal of Islamic Educational Psychology, 1(2), 126146.

Zee, M., \& Koomen, H. M. Y. 2016. Teacher self-efficacy and its effects on classroom processes, student academic adjustment, and teacher well-being: A synthesis of 40 years of research. Review of Educational Research, 86(4), 981-1015. 